University of Nebraska - Lincoln

DigitalCommons@University of Nebraska - Lincoln

Faculty Publications: Department of Teaching, Department of Teaching, Learning and Teacher Learning and Teacher Education

Winter 2011

Feminism, Neoliberalism, and Social Studies

Mardi Schmeichel

Follow this and additional works at: https://digitalcommons.unl.edu/teachlearnfacpub

Part of the Critical and Cultural Studies Commons, Curriculum and Instruction Commons, Gender Equity in Education Commons, Publishing Commons, and the Teacher Education and Professional Development Commons

This Article is brought to you for free and open access by the Department of Teaching, Learning and Teacher Education at DigitalCommons@University of Nebraska - Lincoln. It has been accepted for inclusion in Faculty Publications: Department of Teaching, Learning and Teacher Education by an authorized administrator of DigitalCommons@University of Nebraska - Lincoln. 


\title{
Feminism, Neoliberalism, and Social Studies
}

\author{
Mardi Schmeichel
}

University of Georgia

\begin{abstract}
The purpose of this article is to analyze the sparse presence of women in social studies education and to consider the possibility of a confluence of feminism and neoliberalism within the most widely distributed National Council for the Social Studies (NCSS) publication, Social Education. Using poststructural conceptions of discourse, the author applies second-wave feminist theory and Fraser's (2009) work on neoliberalism as lenses to illuminate the limited attention to women and feminism in this text during the 1980s in order to better understand how women have been marginalized in social studies education and to consider the possibility that the feminist principles present in social studies were taken up in service of neoliberal forces.
\end{abstract}

Keywords: discourse, feminism, neoliberalism, social studies education

Not only are the sources of information [about the history of women] sparse, erratic and inconsistent, there are variations which are hard to interpret and incorporate into a history already dredged out of absences and denial. (Miller, 1996, p. xiv)

In a 2004 piece titled "Women and the Social Studies: The Long Rise and Rapid Fall of Feminist Activity in the National Council for the Social Studies," Margaret Smith Crocco sought to address the "sparse, erratic and inconsistent" attention paid to women's history of which Miller speaks by investigating "the place of feminism within social studies as assessed through evidence of feminist activity within NCSS over the course of the twentieth century" (p. 143). Within her analysis of the National Council for the Social Studies (NCSS) archives, Crocco argued that the most significant feminist activity within the 
organization coincided with the emergence of the women's rights movement in the 1970s. Noting that the attention paid to women in social studies was the result of feminist consciousness in social studies, "a necessary precondition to raising questions about women's roles, visibility, and power" (p. 143), Crocco found that "over the course of the 1980s, activities reflecting feminist consciousness fell off rapidly in number within the organization" (p. 152).

Although Crocco (2008) acknowledged that during the 1970s and 1980s, there were women "and a few men" in social studies education working to get women and women's issues into textbooks, professional committees, and academic conferences, she echoed Miller's lament of "absences and denial" in women's history by concluding that engagement with gender equity issues during this time period "was relatively fleeting" (p. 173). Despite the work of a handful of scholars in social studies education examining these issues, the understanding of why feminist consciousness and women's issues have not taken hold in social studies education has been elusive, as evidenced by the subtitle of one of Crocco's recent chapters: "Gender and Social Education: What's the Problem?" (Crocco, 2006).

Theorist Nancy Fraser (2009) was also concerned with gaining an understanding of the "hard to interpret and incorporate" variations of women's history which have resulted in a modern feminism whose projects, she asserts, are "largely stillborn" (p. 107). She argued, however, that by situating the trajectory of the feminist movement within the recent history of capitalism, we might learn something new that could help us find our way out of the absences and denial Miller described. In an article titled, "Feminism, Capitalism, and the Cunning of History," Fraser argued that key components of feminist ideology inadvertently aided the emergence of a neoliberal economic system in the United States. In particular, Fraser asserted that as feminists gained momentum in their efforts to achieve recognition of women's identity and feminine difference, the movement lost its "emancipatory thrust" (p. 108). Although the feminist focus on culture and identity politics in the 1960s and 1970s was progressive, and effectively reshaped what it was possible to think about women, it shifted attention away from the critiques of economic and political asymmetry which were inherent in the feminist movement. According to Fraser, "the turn to recognition dovetailed all too neatly with a rising neoliberalism that wanted nothing more than to repress all memory of social egalitarianism" (p. 109).

Is it a coincidence that the decline in feminist activity within NCSS during the 1980s described by Crocco parallels the emergence of the "dangerous liaison" of feminism and neoliberalism to which Fraser points? The purpose of this article is to explore the sparse, erratic, inconsistent, and hard to interpret history of women in social studies and to examine the possibility of a confluence of feminism and neoliberalism within the most widely distributed NCSS publication, Social Education. Social studies education discourses held the promise of a rich repository of evidence for this investigation because, as Segall (2004) noted, issues of "power, representation, identity and voice are not only pertinent to social education and research conducted in it but are fundamental to [it]" (p. 161). Taking up Hurren's (2002) premise that, "Something gendered is going on in the construction of Social Studies" (para. 18), as well as Crocco's conclusion that feminist consciousness is absent in social studies, I use feminist theory and Fraser's work on neoliberalism as lenses to 
illuminate the evidence of erratic attention to women and feminism in social studies in order to better understand two research questions:

1. How have women been marginalized in social studies education?

2. Were the feminist principles present in social studies taken up in service of neoliberal forces?

Membership in NCSS includes a subscription to its flagship journal Social Education, which has been in print since 1921, is published seven times a year out of the NCSS headquarters in Baltimore, Maryland, and has more than 25,000 subscribers. Segall (2004) argued that through its alignment with NCSS and its mass distribution, Social Education legitimizes the issues that should be and will be addressed in the field. As such, the documents within Social Education - the articles, advertisements, photos, and features-provide a source of evidence through which to identify the discourses present in social studies education. The exploration of this topic through documents can potentially deepen our understanding of the gendering (Butler, 1993; Hurren, 2002) of social studies education. The texts of Social Education have the potential to reveal the discursive processes which made the marginalization of women a material reality and may also reveal the influence of neoliberal forces upon the instances of feminism which are present.

In the pages that follow, I explore both the state of the women's movement in the 1980s and women in social studies. I then describe poststructural discourse analysis and how I used it to analyze 1980s articles and features within Social Education. Finally, I present my findings and discuss their implication for our understanding of the way Social Education described and positioned women and feminism in the 1980s, provide evidence of a link between feminist and neoliberal forces, and discuss what that might tell us about the discourses available to social studies now and in the future.

\section{Feminism and Neoliberalism}

The achievements of the women's movement in the late 1970s may have indicated that feminists were on the right path. The legalization of abortion, the passage of equal wage laws in some states, and the expansion of women's access to financial credit were all signs that the women's movement was working. In fact, the total number of bills passed by Congress with explicit attention to women's issues between 1970 and 1980 was more than the sum total of all the women-focused bills passed prior to that decade (Davis, 1999). Additionally, in 1978, Equal Rights Amendment (ERA) advocates had gained a four-year extension on the deadline to ratify the amendment and as a result, "the Equal Rights Amendment [made] feminism a regular part of the daily news and the general public's conversation" during this time period (Ryan, 1992, p. 111).

Fraser (2009) contended that second-wave feminism of the 1960s and 1970s achieved these victories by promoting an agenda which was characterized by the intersection of economic, political, and cultural critiques of gender injustice. ${ }^{1}$ She argued that secondwave feminists interwove these critiques as a result of the belief that "overcoming women's subordination required radical transformation of the deep structures of the social totality. 
This shared commitment to systemic transformation betokened the movement's origins in the broader emancipatory ferment of the times" (p. 104). The success feminists enjoyed in the 1970s, especially in terms of political and economic changes, were indicative of the multipronged approach to social change that Fraser described as distinctly second-wave.

However, with the election of Reagan in 1980, and the defeat of ERA in 1982, feminists' efforts to promote their political and economic agendas were thwarted, and any forward momentum they had achieved was overtaken by the need for "defending the ground they thought they had won" (Davis, 1999, p. 433). The assault on the women's movement occurred at the same time that many women's groups, which had formed with the purpose of passing the ERA, disbanded, and the membership in remaining groups dropped (Ryan, 1992). Although these political disappointments were a blow to the movement, there were victories on other fronts. For example, the study of women's issues and experiences blossomed in areas like sociology and history. Women's studies programs proliferated: Davis noted that by 1990, two thirds of American universities offered women's studies courses (1999, p. 223). Additionally, feminist theoretical work and research which addressed the positionality of women of color, third world women, and lesbian women promulgated during the 1980s. ${ }^{2}$ But this increasingly fragmented attention toward differences among women in terms of race, ethnicity, nationality, and sexual orientation, when considered in light of the declining political support for feminist goals, supports Fraser's (2009) contention that the comprehensive second-wave feminist critique had been split by the "selective incorporation and partial recuperation" of the cultural strand of the movement (p. 99). In other words, feminists' focus on women's differences from each other resulted in a type of feminist identity politics which was more focused on recognition than on redistribution or representation.

Fraser (2009) noted that today, feminism is widely seen as having accomplished cultural changes which have not resulted in systemic institutional change: "on the one hand, feminist ideals of gender equality, so contentious in preceding decades, now sit squarely in the social mainstream; on the other hand, they have yet to be realized in practice" (p. 98). Fraser argued, however, that feminist hopes that institutions and structures will eventually catch up with culture are problematic because they obscure the possibility of recognizing that these cultural changes have actually legitimated a transformation of capitalist society "that runs directly counter to feminist visions of a just society" (p. 99). The abrupt decline in feminist political and economic gains, when juxtaposed with the cultural gains they achieved, actually signaled a subtle shift - an appropriation - of feminist goals, and the conscription of feminist efforts "in the service of a project that was deeply at odds with our larger, holistic vision of a just society" (p. 99). Fraser, implying that the parallel successes of a fragmented feminism and neoliberalism were not coincidental, argued that the cultural gains feminists appeared to have made in the 1980s and beyond were made possible through the resignification of feminist principles upon a neoliberal terrain.

As a type of capitalist economic system which uses political structures and social ideology to accelerate the pursuit of self-gain over the common good, the neoliberal transformation of capitalism facilitated deregulation and privatization while valorizing competition, meritocracy, individualism, and personal responsibility (Francis \& Hey, 2009; Fraser, 2009; Harvey, 2007). Davies and Bansel (2007) described neoliberalism as "the transformation of 
the administrative state, one previously responsible for human well-being, as well as for the economy, into a state that ... installs apparatuses and knowledges through which people are reconfigured as productive economic entrepreneurs of their own lives" (p. 248). Although the emancipatory and transformative goals of feminism seem to be incongruent to neoliberalism, Fraser (2009) noted that when neoliberalism emerged in the 1970s and 1980s, the cultural strand of feminism "thrived in these new conditions" (p. 107), as evidenced by the widespread cultural changes which "reshape[d] commonsense views of family, work and dignity" (p. 108). For example, the equation of women's self-worth with work outside the home was particularly conducive to both feminism and neoliberalism. Women of all racial groups and socioeconomic classes filed into the workplace during this time period. The increase of women in the labor force not only allowed more women to access opportunities for personal growth and financial independence, but depressed wages and job security, and made the two-earner family both the norm and a necessity in the modern economy. Fraser contended that promotion of women's work outside the home and the "romance of female advancement" in the labor force turned "a sow's ear into a silk purse" (p. 110). The attention paid to the achievement of the kinds of cultural gains that made it acceptable and desirable for all women to work outside the home obscured the economic exploitation that occurred when more women moved into the workforce. As more attention was paid to culture and recognition, feminism split into factions and became equated with identity politics, which effectively "decoupled" the feminist cultural critique from the economic argument with which it had originally been woven. Through this lopsided focus on and pursuit of cultural recognition, "feminism effectively traded one truncated paradigm for another" (p. 108).

The focus on the recognition and achievement of individual women intensified at the same time as attention to the political struggles of all people fell by the wayside. Women in powerful positions during the 1980s (like Geraldine Ferraro, Sandra Day O'Connor, Margaret Thatcher) became separated from the feminist movement which made their achievements possible: The neoliberal turn worked to portray the achievements of these competitive and individual women, and the status they accumulated, as the result of hard work and merit. This "win" by a small group of women worked against collective movements for equity: If at least some women could win at this game, there was less impetus to critique it. The timing of the public political success of a small number of (certain types of) women and the take up of gender identity politics - in lieu of political and economic critiques - is key to understanding how feminism may have unwittingly buttressed neoliberalism: "After all," Fraser (2009) concluded, "this capitalism would much prefer to confront claims for recognition over claims for redistribution" (p. 113).

\section{Gender and Social Studies}

The documentation of the limited take up of gender and women's issues in social studies education reinforces Miller's (1996) assertion that the attention paid to women and women's history has been sparse, erratic, and inconsistent. Crocco (1999) argued: "Across the social sciences as well as in history, women's contributions have been ignored, underestimated, or marginalized" (p. 8). As such, it comes as no surprise that researchers investigating the 
history of gender in social studies education scholarship have found that in regard to gender issues, there is little evidence that the field has made significant strides in achieving equity. The work conducted to analyze the integration and representation of women into social studies points to absence and void. For example, in a comprehensive review of gender in social studies education research published in 1985, Hahn et al. reported that many textbooks retained a sex bias and that there was only a short list of textbooks in which "sexist language occurs less frequently, a few more famous women appear, and photos show women in a greater variety of roles" (p. 281). Hahn also led the team of social studies education researchers who reviewed the literature in the discipline 20 years later (Hahn, Bernard-Powers, Crocco, \& Woyshner, 2007). In their review of gender within social studies research between 1985 and 2005, the authors lamented that there was:

little empirical evidence to show that social studies has become more gender equitable, has devised proven pathways to more gender-equitable practice in the field, has addressed the intersectionality of race/ethnicity, class, and gender, or has made an identifiable contribution to more gender-equitable national and global societies. (p. 336)

They concluded that the only improvements achieved seemed to be related to the modest increases in the representation of women in curriculum guidelines, standards, and textbooks. Crocco (2006) asserted that attention to gender in social studies has been interpreted as the "redressing [of] past imbalances in the treatment of women-in textbooks, curriculum frameworks, historiography and leadership roles in the field.... Most social educators would probably argue that slow, incremental progress has been made over the last twenty years" (p. 176).

These findings indicate that there were modest gains in the presence of women within the discourses of social studies education. However, the shifts in the discourse that these scholars identified, such as the reduction of sexist language and the occasional inclusion of women in textbooks and standards, were limited to the strand of feminism that Fraser (2009) referred to as a cultural critique. There does not seem to be an indication that the attention paid to women and gender in social studies, attention which Crocco (2004) argued was the result of feminist consciousness, incorporated the feminist political and/or economic critiques which Fraser asserted were inherent components of feminism. The changes within social studies that were achieved in terms of women and gender were limited to aspects of the field which encompassed cultural recognition and identity, facets of feminism which Fraser argued inadvertently strengthened neoliberalism.

The purpose of this article is to explore the discourses within a social studies education text in order to delve into the subtle shifts in the discourse that gender and social studies scholars have reported, while also applying Fraser's analysis of the convergence of neoliberal and feminist forces. The perspective that documents can illuminate these discursive forces is based upon Weedon's (1997) assertion that "language is the place where actual and possible forms of social organization and their likely social and political consequences are defined and contested" (p. 21). This belief reflects a poststructural stance that positions language and discourse as material and productive forces which construct what it is 
possible for us to think. In the following section, I articulate the theory of discourse used to analyze the data presented in this article and will discuss the possibilities and limitations of this perspective. I then discuss what this take on discourse might help us understand about gender, feminism, and neoliberalism in Social Education.

\section{Theoretical Perspective}

My interest in language within this article is not what a text reveals about the author's individual beliefs and opinions. I wanted to explore how the author's choices might reveal the discourses that shape what is possible to think in a place and time. Therefore, I used a poststructural conception of discourse to conduct this research. Poststructural philosopher Michel Foucault, and the scholars who have taken up his work, see discourses not as groups of words or sets of signifiers which simply refer to or describe reality. Instead, discourses are what Foucault (1969/1972) described as "practices that systematically form the objects of which they speak" (p. 49). This poststructural conception of discourse, which is central in the work of Foucault, seeks to "reveal and describe" the work of language beyond its use as "signs to designate things" by examining the forces which discourses unleash upon our lives (p. 49). I drew upon these poststructural conceptions of language and discourse to analyze gender and feminist discourses in Social Education and to ask questions about the consequences of what is and is not within those texts.

Scholars using a Foucauldian perspective position discourse as the mode through which we understand and move through the world. This idea is described by Lather (1991), who said, "Whatever 'the real' is, it is discursive" (p. 25). In other words, what it is possible for us to think and know is made possible only through the discourses to which we have access. Our repeated iterations of discourses - discourses of women, education, and social studies, to name a few - reinscribe and stabilize their meaning (Butler, 1990, 1993). Discourses are material and productive forces which construct our reality and our conception of what our reality is.

However, discourses also limit what is possible to think and say about ourselves and our world. St. Pierre (2000) posited "within the rules of discourse, it makes sense to say only certain things. Other statements and others way of thinking remain unintelligible, outside the realm of possibility" (p. 485). Discourses not only open the world to us but also regulate what is impossible to think and say. This occurs because the discourses within which we operate define what it is possible for us to understand as true and untrue. Foucault (1981) highlighted the contingency of truths by describing discourses as shaped not by truth but by a will to truth. In this sense, the truths which undergird and define a discourse are "not the dumb existence of a reality, nor the canonical use of vocabulary, but the ordering of objects" (Foucault, 1969/1972, p. 49). The underlying and assumptive truths of a discourse reveal its will, or the goal of the work the discourse seeks to achieve. This means, for example, that what we accept as true about the field of social studies education produces a particular "ordering of objects" that serves a particular and material purpose.

The will to truth that orders our discourse may not always be evident to us. Foucault (1981) argued that although discourses and truths are historically conditioned, the distinction between truths and falsehoods may appear to be "neither arbitrary nor modifiable nor 
institutional nor violent" (p. 54). In this sense, truths regulate thinking and language in ways which make their exclusions and constraints invisible to those who participate in the discourse. This means, for example, that an author may be unaware that the forces regulating her speech are the result of "a particular network of powerful intellectual and disciplinary expectations" (Bové, 1995, p. 54) or that the words she chooses to write reflect and produce "a material force, a capacity to constrain, to shape, to coerce, as well as to potentiate individual action" (Davies, 2003, p. xii).

Poststructuralists are interested in this hidden and regulative function of discourse, particularly for the potential to expose the contingency of truths and beliefs which may appear to be commonsensical or natural. But discourses, and the truths with which they align, are not fixed products created by the powers that be and then handed to us. Davies and Harré (2000) posited that "discursive practices constitute the speakers and hearers in certain ways and yet at the same time are resources through which speakers and hearers can attempt to negotiate new positions" (p. 105). The words and ways of thinking an author has available to her, therefore, are the product of a collective meaning-making process which is dynamic, fragmented, and potentially resistible. The aim of postructuralist discourse work is to find the openings and ruptures in the discourse where resistance can and does occur, a purpose reflected in Foucault's (1981) statement that one of the goals of his work was to discover how truth is a choice that can be "repeated, renewed and displaced" (p. 70). Foucault's interest then was not a humanist pursuit of gaining a more accurate understanding of what is true and false but coming to an understanding of how truths come to be perceived as true, the discursive technologies that make them possible, and how this understanding has the potential to disrupt those truths (Mills, 2004).

By examining the texts of a historical period through this poststructural discursive lens, we gain much more than an understanding of what any particular author believes. Instead, through an analysis of the truths underlying claims, statements, and absences in a collection of texts, we gain an understanding of technologies regulating and producing the will to truth in that space, and gain an insight into the lived and negotiated boundaries demarcated by the discourse. Texts also provide us with artifacts of language practices and discourses that offer a glimpse of the terrain upon which confrontation and displacement of competing discourses occurs. Through its articles, features, ads, and omissions, the texts of Social Education during the 1980s provide a bird's eye view from which to consider the discursive artifacts about women in the magazine in order to ask, "in what specific contexts, among which specific communities of people, and by what textual and social processes has meaning been acquired?" (Scott, 1988, p. 35). Discourse analyses can reveal how actions and behavior were legitimized and how the texts constructed and conditioned knowledge (Segall, 2006) and provide a point from which to theorize the possible clashes of the discourses circulating in the texts in the most widely read publication in social studies education.

However, as a researcher, a social studies educator, and a participant in this culture, my ability to read in to the discourses evident in Social Education, and to represent them in a way which resisted dominant paradigms, were constrained by own struggle to see past the normative assumptions which have shaped my view of the world, of social studies education, and of gender and feminism - the discursive truths which have constituted my 
reality. And of course, as Davies (2003) reminded us, "poststructural theory is itself a discourse" (p. xiii) which possesses its own will to truth and productive goals. This makes my findings admittedly messy, partial and contingent, because "any attempt the [poststructural] researcher makes to tell what it is s/he sees/hears/smells/feels/believes/desires is understood to produce no more than a possible reading" (Davies, 2003, p. 144). It is important to note here, however, that the goal of this article is not to produce the truth but to open up complicated new spaces in which to explore the gendering of social studies education and enhance our understanding of how it happens, in hopes that it might "generate possibilities for things to happen that are closed off by the epistemologies of certainty" (Stronach \& McClure, 1997, p. 5). Although this theoretical paradigm could be a risky move, especially within a research ecosystem in which positivist work rules, I am comforted by Lather's (1996) argument: "Refusing textual innocence and an untroubled realism, representation is practiced as a way to intervene, even while one's confidence is troubled" (p. 539).

\section{Mode of Inquiry}

The data presented here is subset of the data generated in a study of the discursive construction of women and gender in Social Education in the 1980s. Using poststructural ideas about language and discourse, I conducted a discourse analysis, drawing inspiration from discourse analysis scholars (Andersen, 2003; Davies, 2003; Foucault, 1975/1995; MacLure, 2003; Mills, 2004; Prior, 2003). I reviewed each issue published during the decade, page by page, paying close attention to the context of the language and images in order to identify and locate discursive patterns relating to women and gender. I made notes of the text events around and about women as well as the conspicuous absences of women and women's issues I found in the journal, attending not to just the content of the events but also to the ways in which women were positioned within them.

As I wrote up this data, I was analyzing those text events and developing an interpretation of the discursive forces at work, while at the same interrogating my own ideas and comments. This process reflects the writing as inquiry paradigm promoted by Richardson and St. Pierre (2005), who posited "writing is thinking, writing is analysis, writing is indeed a seductive and tangled method of discovery" (p. 967). From this perspective, the acts of looking at data and writing up research notes are processes through which knowledge and understanding of topic develop. I made sense of the data as I wrote the research notes. Making decisions about what to record in my notes and how to describe it led to a consideration of what the textual event under review might mean.

I conducted my initial research by examining the presence and absence of women and the construction of gendered identities in Social Education texts during the decade. As I wrote, one of the understandings I began to develop was how women had been marginalized or almost completely excluded from the text. The unbalanced ratio of female to male authors $(35 \%-65 \%)$ and the near absence of attention to women and women's issues within the publication characterize the ways in which women had been shaped and ordered in the discourse. After I had written my way through these findings, I read Fraser's (2009) work on the intersection of feminism and neoliberalism. Upon reading her article, I used 
her theory to reanalyze the data, and in particular, the text events in which feminism was explicitly addressed. In her discussion of discourse research, MacLure (2003) asserted:

The hardest thing to see in any text is that which poses itself as natural and unquestionable. So a first step toward opening up any text would be to watch and wait for something - often a little, seemingly inconsequential thing - that somehow catches your attention, puzzles you. (p. 82)

In my discourse analysis of Social Education, I used the contrasts that caught my attention to try to open up the work being done by the text. In the next section, I present an analysis of two excerpts from the data which, through a discussion of contrasts, demonstrate some of the ways in which women were marginalized. In order to do this work, I drew on secondwave feminist theorists (Alcoff, 1988; Haraway, 1988; Rich, 1976; Smith, 1987) to identify the ways in which women and women's issues were framed. Because I was interested in trying to access and understand the discourses available to the social studies community at this point in history, it was reasonable to use feminist work which was roughly contemporary to the Social Education publications under review in order to think about the discursive possibilities which would have been available to authors. The use of second-wave feminist theory is particularly helpful for thinking about the potential interaction, or lack thereof, between feminist discourses and the attention paid to women in Social Education at the same time.

In the second section of my findings, I used the contrasts between the different ways that feminism was described and deployed at three points during the decade and applied Fraser's theory to suggest the possible confluence of feminism and neoliberalism. In order to apply Fraser's theory to Social Education, I examined text events in which feminism was invoked explicitly to address and describe women's inequality. I used Fraser's definition of feminism as an intersectionist social movement with an emphasis on ending gender injustice (pp. 103-104) and her descriptions of the three strands of feminism - political, economic, cultural - to analyze which of those components of feminism were deployed and ignored in these texts.

\section{Findings}

\section{An Interview with Smeal}

Among the nearly 1,000 articles published in Social Education between 1980 and 1989, only one featured the American women's political movement as the primary topic. This piece, published in the February 1983 issue, is an interview with the outgoing president of the National Organization for Women (N.O.W.), Eleanor Smeal (Langer, 1983a). The cover photo of this issue of Social Education featured a full-size black-and-white photo of a group of six suffragettes holding a handmade banner with the following Susan B. Anthony quotation: "No self respecting woman should wish or work for the success of a party that ignores her sex." Within the About This Issue ... section featured on the content page, Howard Langer, the editor of Social Education, wrote: 
We can think of no more appropriate time to carry an interview with Ellie Smeal. ... Congress has designated the week of March 6-12, 1983, as Women's History Week. You will find a great deal on the Women's Movement for both classroom and faculty room discussion: the gender gap, the Reagan Administration's policies toward women, abortion, the ERA. (February, 1983, p. 84)

Between 1982 and 1984, Social Education published four interviews conducted by Langer. The interview with Smeal is the only interview of either a woman or a political figure. The other interviews were conducted with male writers: reporter Theodore White (Langer, 1982), journalist William Shirer (Langer, 1983b), and humorist Art Buchwald (Langer, 1984). In the introduction to the Smeal interview, Langer (1983a) observed that with the number of interviews Smeal had conducted over the last several days, "one would expect her to show some fatigue. But she is so enraged about the deal that women have been getting from this [Reagan] administration, that her intensity is deep" (p. 112). Langer commented that, "as [Smeal] recounts the incident of the Reagan press conference where he snickered at the idea of sex harassment, she builds a quiet, controlled fury" (p. 112). The introduction also included background information on Smeal, who is described as the fourth child and first daughter of her Catholic family. He noted that while Smeal was a student at the University of Florida, she met and married her husband, who was studying engineering and that she became involved with N.O.W. while recuperating from an illness that left her bedridden for a year, after she discovered that there was no disability insurance for wives and mothers.

When comparing the introduction to Smeal's interview with the introduction to the other three interviews conducted by Langer, Smeal's introduction is the only one which: (a) provides information regarding where the interviewee met their spouse, the spouse's occupation, and the interviewee's position as a child or as a parent; and (b) provides assessments of Langer's observations of the mood and/or emotions of the interviewee. These distinctions provide some insight into the discourses of about women available and circulating in 1983. In a feminist analysis which emphasizes positionality, Langer's move to include references to Smeal's family relationships could signal a shift away from the typical patriarchal interview protocol which would have ignored the interviewee's status as a parent or spouse as irrelevant details. Alcoff (1988) argued that the concept of positionality allows women "to take up a position within a moving historical context and to be able to choose what we make of this position" (p. 435) and that the place where women find themselves can be used "as a location for the construction of meaning" (p. 434). It could be argued, therefore, that Smeal's positioning as a wife and mother is a place from which to produce a richer and more contextual understanding about what a woman who is a mother, wife, and national political figure, can be. Therefore, instead of critiquing the inclusion of this information, some feminists might laud this positioning for the powerful "meaning" of being a woman it produces.

Alcoff (1988) also described positionality as making women's identity "relative to a constantly shifting network of elements involving others, the objective economic conditions, cultural and political institutions and ideologies and so on" (p. 433). The position in which Smeal is placed within the social "network" in the descriptions of her role as a wife 
and mother, for example, might also be interpreted as serving to pin her down within potentially subjugated positions, while in comparison, the male interviewees were represented as unattached and untethered. Haraway (1988) argued that "only those occupying the positions of the dominators are self-identical, unmarked, disembodied, unmediated, transcendent" (p. 586). Although the men are not described in ways (such as son, father, husband) which attach them, or situate them in relation to others, Smeal's positioning as wife, mother, and daughter defined her place not only in relationship to others but also placed her in positions which, within a patriarchal society, are understood in terms of not being male and not being privileged.

Rich (1976) argued that patriarchy's power to determine women's gender identity is one of its greatest successes. Within patriarchy, Rich asserted, the construction of motherhood is institutionalized, and as a result, women are stripped of the flexibility to determine how, when, and what kind of mother they can be. This control over the conceptions of motherhood excludes women from some aspects of public life, as a good mother, as constructed by a patriarchal society, puts her family's needs before her interest in the outside world and her own ambitions and achievements. In this sense, motherhood acts as "the institution which aims at ensuring that that potential [of women's reproductive power]and all women - shall remain under male control" (Rich, 1976, p. 13). The explicit inclusion of the description of Smeal as someone's wife and mother marked her in a gendered discourse as subjugated and called into question her gender identify by juxtaposing institutionalized conceptions of motherhood with her status as a national political figure. The description of Smeal as "enraged" and as in the process of building a "quiet, controlled fury" not only reinscribed the perception of women as emotional but also played into the stereotype of the perpetually perturbed feminist.

We are reminded by Smith (1987) that texts contain implicit social relations "of which the passage does not speak" (p. 115). Langer's description of Smeal enabled readers to know some things about her, and to know those things in specific ways (Segall, 2010). To frame the president of the National Organization for Women as a tired and emotional wife/ mother/daughter is an expression of the social relations of the time and a certain way of thinking about women. That none of the male interviewees were described similarly in their interviews buttresses the assertion that the language used to situate Smeal's gendered location could be interpreted as a reinscription of male subjectivity - the state of being male-as normal and therefore, unnecessary to explicate in discourse, reinscribing male privilege and the subjugation of women.

\section{Women and Gender in the Curriculum}

The cover of the March 1987 special edition of Social Education, titled "Getting Women and Gender into the Curriculum Mainstream: How To Do It," featured two black-and-white photos: one was a portrait of a Victorian-era mother and an infant child in a baby carriage, the other depicted a 1940s female metalworker in factory garb. This issue offered six separate articles written by women about women and gender in social studies, including pieces on women's history, feminist pedagogy, and a resource list detailing gender-balanced sources. With more than 46 pages dedicated to women's issues in social studies education, this special edition of Social Education represented the most attention paid to women in one 
issue during the decade. However, as guest editor Mary Kay Tetreault (1987) noted in her introduction, the impetus for the issue emanated from the decline of attention given to gender issues at that time:

A puzzling phenomenon has appeared during the past decade in relation to women, gender and social studies. On the one hand, there has been a dramatic increase in the number of women's studies, gender studies, and mainstreaming program and courses in higher education, while on the other, there has been a decrease in the program and courses in elementary and secondary education (Schmitz, 1985). (p. 167)

Tetreault pointed to research that indicated that although the number of specific women's issues courses had declined, there was an interest in incorporating the topics that had been addressed in those classes into the mainstream social studies curriculum. The purpose of this issue, then, was to support classroom teachers' efforts to incorporate issues of gender, women, and feminism into the social studies curriculum.

Ironically, given this proclaimed focus of the issue, one of the differences between this special topic issue and most of the special issues published on other topics during the decade, was the absence of reproducible classroom activities. Many of the issues of Social Education published during the 1980s include a section called the Supplement. In this issue, the supplement was printed on a different kind of paper than the rest of the issue, was a different color, and was three-hole punched. Placed in the center of the magazine, it was designed to be torn out and featured specific directions for the implementation of social studies classroom activities. Although Tetreault expressed a desire that this special issue be used by those with an "interest in incorporating women into the traditional curriculum" (1987, p. 167), the issue did not provide teachers with explicit lesson plans or activities to use in the classroom. Some of the authors discussed feminist approaches to pedagogy and women's history resources in the articles, but the "tear out" lesson plan supplement of this issue, titled "How To Do It: Global Perspectives Through Children's Games" (Nickell \& Kennedy, 1987), described a series of games to introduce students to the cultures of different countries, including India, China, and Nigeria. This supplement is inserted within the pages of Francis Maher's article, titled "Inquiry Teaching and Feminist Pedagogy" (1987).

The disconnect between the supplement and the topic of the special issue made this issue of Social Education different from most of the special-topic issues in the 1980s. For example, in the March 1985 special edition of Social Education on the environment, the special features included a supplement with specific lesson plans and step-by-step instructions for teachers to conduct an environmentally conscious scavenger hunt (Charles, 1985). And the November/December 1983 special issue on nuclear arms featured a supplement with two classroom-ready activities: a nuclear arms race unit for teacher use (Totten, 1983) and a lesson plan based on a novel depicting a Japanese account of the bombing of Hiroshima (Scott, 1983). The special issue featuring women and gender issues in social studies did not include specific plans or reproducible student activities and therefore failed to provide teachers with an easy-to-use or ready-made way to incorporate women's issues or feminist practices into their classrooms. Therefore, readers were left to their own devices 
to implement the suggestions for incorporating women into the curriculum which were promoted in this issue. This could be read through Smith (1987) as an example of a gendered exclusion of what counts from the discourse:

[Women] may support, facilitate, encourage, but their action does not become part of the play. ... What women have to say may simply remain unsaid. Or it is treated as a byplay - not really integral to the game. If it comes into play at all it is because a male player has picked it up and brought it into play as his. (p. 32)

The absence of readily reproducible lesson plans may indicate that women were still nonintegral byplays within social studies. However, the mere presence of an interview with the N.O.W. president and of a special topic issue on women's history and feminist pedagogy are indications that feminist forces were present in the discourses of Social Education during the 1980s. In the following section, I examine contrasts in the descriptions of feminism and turn to Fraser to consider the confluence of feminist and neoliberal forces.

\section{Neoliberalism}

In her contribution to a special issue titled "The Future and the American Dream" in 1982, Jean Dresden Grambs asserted that the Civil Rights Movement had forced (presumably white) women to ask, "If Blacks can ask for and expect to get equality, why can't women?" (p. 407). She argued that this questioning "resulted in the massive reexamination of women's roles and women's work" (p. 407) and that women's view about the American Dream had shifted: "There is no denying that there is a new face on women's activities in this decade. So impressive have been the changes in women's roles that social scientists now talk with academic certainty about the women's movement" (p. 407).

Grambs (1982) predicted that it was "highly probable" that the women's movement would achieve some of its key goals within "a few generations," including "the removal of the sexist tracking of women and men into different jobs with different, and lower, levels of achievement for women" (p. 407). Additionally, she envisaged that "Political leadership will be in the hands of women and men, very possibly in equal amounts" (p. 407). She noted that hard as this is for today's conservatives to understand, once the concept of equity has been acknowledged as referring to all human beings, and laws have been written which implement this concept, the movement of women in to public life and the marketplace cannot be stopped. (p. 407)

Grambs provided an extensive list of the changes that women were hoping to achieve, which included cultural, economic, and political changes. She told social studies educators that they had a responsibility to support women's achievement of these goals by educating themselves about women's history, discussing women's issues and women's equity with their students, stressing participation in the political system as a right of women and men, and helping students identify role models who had transcended gender stereotypes (p. 409).

Grambs's emphasis on economics, politics, and culture, and her calls for social studies educators to attend to issues on each of these fronts, is representative of the kind of secondwave, emancipatory feminism that Fraser (2009) described as promoting an "structural critique of society" (p. 97). By weaving together these three distinct perspectives, Fraser 
argued, feminists were able to generate "a critique that was simultaneously ramified and systematic" (p. 99). In Grambs's optimistic discussion of the women's movement and the American dream, she described the structural and cultural changes she felt would be an inevitable result of the movement's momentum. Additionally, in her instructions for educators, Grambs wove together issues which spoke to gender injustice in political, economic, and cultural systems, an understanding of women's subordination which Fraser contended that second-wave feminists understood was "grounded in deep structures of society" (p. 103). Grambs's use of feminism in this text is clearly aligned with Fraser's descriptions of second wave feminism.

Throughout her interview, Smeal echoed much of the same optimism and forwardthinking rhetoric evident in Grambs's article. Smeal made repeated claims regarding the achievement of the women's movement as a political force and asserted that women were working toward establishing an independent political movement, and were "making the difference in changing the course of politics in this country" (Langer, 1983a, p. 118). The statement of these kinds of goals align with Fraser's description of the transformative aspirations of feminism of the time.

Additionally, Smeal addressed economic injustices throughout the interview. In response to a question from Langer about the existence of a gender gap, Smeal replied,

I think women have been hurt economically by [the Reagan] Administration and are becoming the economic have-nots ... more and more women are dependent on their own incomes. They see the Equal Rights Amendment and similar issues as issues of economic opportunity. (p. 115)

Furthermore, Smeal critiqued President Reagan for his alignment with the theories of writer George Gilder. Gilder is described by Harvey (2007) as a pundit whose work was supported financially by the think tanks that were affiliated with the "centres of neoliberal orthodoxy" (p. 54). Smeal stated that Gilder was promoting an economy in which "women must be totally elastic as workers, entering and leaving the marketplace, working at jobs for money, according to the demands of the market" (Langer, 1983a, p. 115). Smeal alluded to her belief that this economic perspective signaled the presence of new economic and political forces at work, which she described as a "reactionary political movement that has treated women and their issues as its whipping persons" (p. 118). She concluded, "The fear is that if we don't take the New Right seriously enough, more reactionaries will win again. ... I believe that our strength is a response to our times because the political threat is so great to all of us" (p. 118). Although Fraser asserted that the feminist economic and political critiques were eventually decoupled from the movement, in this 1983 interview with Eleanor Smeal, not only were politics and economics still hinged to feminism, but Smeal warned of a nefarious tide on the horizon which threatened feminist achievements and efforts on these fronts.

By contrast, within the 1987 special issue on "Getting Women into the Curriculum," the presence of what Fraser termed resignified feminism, characterized by an exclusive focus on recognition, was pervasive. The articles in this issue dealt exclusively with dilemmas and strategies for infusing women and women's difference into textbooks, curricula, and 
standards. The authors sought to promote gender as a valid category of analysis within social studies education and promoted feminist pedagogies to help students, "come to terms with our differences and the multiple capacities and social responsibilities within ourselves" (Maher, 1987, p. 192). For example, in her article highlighting the differences between inquiry teaching and feminist pedagogy, Maher (1987) stressed "the central goal of [feminist pedagogical] methods is not the construction of one overall solution ... but an understanding of the ramifications of different problems and solutions in different contexts" (p. 188). She provided an example of this approach by describing how the Great Depression and New Deal might be taught from a feminist approach through the use of first person narratives. Maher stressed that the feminist use of first person accounts would be distinguished from other teaching strategies by the questioning of the "differential effects of the Depression and the New Deal on people's lives" in a way that would lead students to not a "general right answer or universal conclusion, [but] a fuller picture of a complex society" (p. 191).

This focus upon the differential experiences of people of different gender, class, and ethnicity aligns with Fraser's critique of resignified and fragmented feminism as solely focused upon cultural recognition and identity politics. Maher's goal for the feminist classroom she described here was not a space in which students were encouraged to question and critique the political and economic structures which led to the differential impact of the depression on different social groups. The kind of second-wave feminism Fraser described would have demanded much more than "a fuller picture of a complex society" as a result of a feminist investigation of the Depression and New Deal by bringing all three prongs of the feminist critique-political, economic, and cultural-to analyze this historical event.

The focus on women's identity and inclusion characterized all of the articles featured in this special issue, which seems to support Fraser's criticism that the feminist movement developed a single-minded pursuit of recognition that may have both emerged from and facilitated neoliberalism. Tetreault and Maher's calls for change in social studies education, for example, refrain from an examination or explicit calling out of the structures within the discipline, and perhaps even within NCSS, which had obstructed the inclusion of women to that point. The absence of specific references to economic and political transformation in the 1987 issue is particularly evident when these articles are compared to the commentary and critiques of Grambs and Smeal in the early part of the decade. Their calls for systemic transformation in 1982 and 1983 were clear: by contrast, the calls for change in the 1987 issue were muted.

When considered in the context of the sparse attention paid to women and women's issues during the 1980s, that these articles, and this special issue, were chosen for attention and emphasis within Social Education is an indication of a change in the discourse and provides an alternative way for thinking about the feminist work present in Social Education. The argument that women's history must be included in social studies education and that feminist pedagogies were valid, implies a certain critical discourse circulating in the field. The achievements of these female authors, and their willingness and ability to break into a male-dominated field were an important step forward in making social studies a more inclusive discipline. It would be difficult to imagine, for example, that this special issue 
would have been possible during the 1960s or 1970s. Therefore, the special topic issue and the feminist theory on which the articles were based, as well as the presence of the Smeal interview and the Grambs piece, could certainly be interpreted as progress.

There are also alternative ways of thinking about Fraser's theory about the confluence of feminism and neoliberalism. Fraser's earlier work (Fraser, 1995, 1997; Fraser \& Honneth, 2003) focused specifically on the tension between redistribution and recognition within the Left. In this work, Fraser (1995) argued, for example, that because of the emergence of identity politics, and its claims for recognition of difference, "cultural domination supplant[ed] exploitation as the fundamental injustice. And cultural recognition displace[d] socioeconomic redistribution as the remedy for injustice and the goal of political struggle" (p. 68). Fraser posited that the pull between calls for systemic economic change and the recognition of cultural difference created a dichotomy which hindered the efficacy of the Left's agenda. Young (2008) critiqued Fraser for creating an explanatory framework in which recognition and redistribution were polarized. She argued that "it is difficult to see how a feminist politics of recognition 'pulls against' a feminist politics of redistribution" (p. 104). Instead of placing cultural and economic concerns in competition, Young promoted a theoretical approach to thinking about an agenda on the Left in which "culture becomes one of several sites of struggle interacting with others" (p. 105). Although Young's comments were not directed specifically at the Fraser (2009) article, which was the foundation for the analysis in this project, her critique of the polarization created in a framework that pits cultural recognition issues against other social concerns (political or economic) is germane to Fraser's more recent argument that the emphasis on recognition derailed the feminist movement. By suggesting that it would be "theoretically and politically more productive to pluralize categories [such as political, economic and cultural struggles] and understand them as differently related to particular social groups and issues" (p. 91), Young provides an alternative conception for thinking about what feminism was or was not doing in Social Education and elsewhere during the 1980s.

\section{Discussion and Conclusion}

One of the challenges in trying to identify a possible intersection of feminism and neoliberalism in a text like Social Education is closely related to Miller's assertion in the quotation I used to open this article: The attention paid to women is sparse, erratic, or absent, making an interpretation of the discourses about and around women very difficult to dredge up. The number of examples in the texts of Social Education which referred, explicitly or implicitly, to women, women's issues, gender, or feminism were few. This limited dataset makes conclusions tenuous, and might have convinced me to abandon this project altogether. However, in her description of textual deconstruction, Spivak (1974) contended that by working within and through the marginal text and reversing the hierarchy, or as Mazzei (2004) stated, "to give preference to what has been subjugated" (p. 27), a text can be reappropriated to show us what we do not know.

The bodies of work by Crocco and the other scholars researching in gender and social studies make it very clear that feminist and gender discourses are not present in this field, but we do not seem to have a good understanding of how feminist work has been excluded 
from social studies. As I argued earlier in this piece, the analysis of the official discourses of social studies education hold promise for contributing to this understanding. However, St. Pierre (2000) captured the elusiveness of discursive work when she argued:

When we try to get to the bottom of language and meaning, we find that we are lost in the play of discourse-not by any means an unpleasant experience, but one that can be frustrating for those who want to know exactly what is going on. (p. 477)

This article does not attempt to fill the void in our understanding of "what [was] going on" and how women's marginalization occurred. But by illuminating some of the discursive forces at work within the text of a ubiquitous social studies education publication, and using theory to understand it, I seek to provide potential examples and explanations of how women have been marginalized within this field.

Adding Fraser's argument about the liaison of feminist and neoliberal discourses to the mix further complicates a landscape which Miller described as already "hard to interpret." There are limitations to both her theory and the data which might point to the interaction between feminism and neoliberalism, particularly in a publication which rarely attended to feminist or women's issues. But by disrupting our assumptions about what feminism is and has been doing in the last several decades, Fraser provides new points of interrogation from which to consider how exclusionary work has been done. Her work may provide us with some new questions to ask about gender work and a new and better way of understanding feminism within social studies education during a critical time period. For example, Crocco (2004) has argued that there was feminist consciousness in social studies education, and specifically NCSS, in the 1970s. Did those forces exhibit the kind of comprehensive transformative critique Fraser described as second-wave feminism, or solely the cultural critique, as the evidence I presented here from late 1980s suggests? If more political and economic critiques, like those presented in the Grambs article and the Smeal interview, had been produced and printed in Social Education, would it have made a difference? Would social studies be more critical? Do these more comprehensive feminist critiques exist in other $\mathrm{K}-12$ disciplines? For example, have our feminist friends in fields like literacy and language been more successful in engaging these more fully fledged feminist critiques? Is a more critical discourse present in Australian, British, or Canadian feminist social education work? Would it be productive to find some strategies for this feminist work by looking for more successful models?

I propose that feminists and their advocates within the field of social studies education need to answer these and other questions in an effort to understand how we have found ourselves in this gender drought. We need to take a look at ourselves as social studies education researchers, both in the past and the present, in order to understand how what we have chosen to attend to, or not, has contributed to the absence of women from the discourses of social studies education. This project examined a historical period because it seems very important to understand what has contributed to the persistent exclusion of women from the field before we might possibly be able to do things differently, and think differently, about gender in social studies education in the present. However, as I write 
this, members of this community are making topical, theoretical, and methodological choices that are shaping and ordering the gender status quo in the field. Revealing the origins of the discursive forces at work, and disrupting and making contingent the taken for granted assumptions which shape the field, are steps toward opening up new options and possibilities in our ongoing work in social studies.

\section{Notes}

The author would like to thank Stephanie Jones, Meg Monaghan, Hilary Conklin, Hilary Hughes, Alex Cuenca and Joseph Pate for their feedback on this article.

1. The history of feminism is often divided into three different waves. First-wave feminism is the label generally used to denote women's political efforts in America during the 18th and 19th centuries and the suffrage movement. First-wave feminism culminated in the ratification of the 19th amendment. Second-wave feminism is linked to the Civil Rights Movement and a type of feminism which, Nicholson (1997) noted, "had been deeply affected by the insights of Marxist theory" (p. 2) Third-wave feminism was rooted in second-wave feminist work in the 1970s and 1980s but emerged as a different kind of feminism in early 1990s. Third-wave feminism is often described as a reaction to the lack of attention paid to class, race, sexuality, and nationality among second-wave feminists. Freedman (2003) contended that third-wave feminists sought to "go beyond the second wave of feminism by forging a more racially and sexually diverse movement that emphasized female empowerment rather than male oppression" (p. 6). According to Freedman, the work of third-wave feminists effectively "transformed an initially white, European, middle-class politics into a more diverse and more mature feminist movement" (p. 6).

2. For examples, see Anzaldúa, 1987; Davis, 1981; Mohanty, 1988; Moraga \& Anzaldúa, 1981; Rich, 1986; Trinh, 1986.

\section{References}

Alcoff, L. (1988). Cultural feminism versus post-structuralism: The identity crisis in feminist theory. Signs, 13(3), 405-436.

Andersen, N. (2003). Discursive analytical strategies: Understanding Foucault, Koselleck, Laclau, Luhman. Bristol, UK: Policy Press.

Anzaldúa, G. (1987). Borderlands: The new mestiza $=$ La frontera. San Francisco, CA: Spinsters/Aunt Lute.

Bové, P. A. (1995). Discourse. In F. Lentricchia, \& T. McLaughlin (Eds.), Critical terms for literary study (pp. 50-65). Chicago, IL: University of Chicago.

Butler, J. (1990). Gender trouble: Feminism and the subversion of identity. New York, NY: Routledge.

Butler, J. (1993). Bodies that matter: On the discursive limits of sex. New York, NY: Routledge.

Charles, C. (1985). Using the natural world to teach and learn globally. Social Education, 49(3), 213-217.

Crocco, M. S. (1999). Introduction. In M. S. Crocco \& Davis, O. L. (Eds.), "Bending the future to their will": Civic women, social education, and democracy, (pp. 1-16). Oxford, UK: Rowan \& Littlefield.

Crocco, M. S. (2004). Women and the social studies: The long rise and rapid fall of feminist activity in the National Council of the Social Studies. In C. Woyshner, J. Watras, \& M. S. Crocco (Eds.), Social education in the 20th century (pp. 142-159). New York, NY: Peter Lang. 
Crocco, M. S. (2006). Gender and social education: What's the problem? In E. W. Ross (Ed.), The social studies curriculum: Purposes, problems, and possibilities (3rd ed., pp. 171-193). Albany: State University of New York Press.

Crocco, M. S. (2008). Gender and sexuality in social studies. In L. S. Levstik, \& C. A. Tyson (Eds.), Handbook of research in social studies education (pp. 172-196). New York, NY: Routledge.

Davies, B. (2003) Frogs, snails, and feminist tails. Cresskill, NJ: Hampton Press.

Davies, B., \& Bansel, P. (2007). Neoliberalism and education. International Journal of Qualitative Studies in Education, 20(3), 247-259.

Davies, B., \& Harré, R. (2000). Positioning: The discursive production of selves. In B. Davies (Ed.), A body of writing: 1990-1999 (pp. 87-106). Walnut Creek, CA: AltaMira Press.

Davis, A. (1981). Women, race, E class. New York, NY: Random House.

Davis, F. (1999). Moving the mountain: The women's movement in America since 1960 (2nd ed.). Urbana: University of Illinois Press.

Foucault, M. (1972). The archeology of knowledge and the discourse on language (A. M. Sheridan Smith, Trans.). New York, NY: Pantheon Books. (Original work published 1969)

Foucault, M. (1981). The order of discourse. In R. Young (Ed.), Untying the text: A post-structuralist reader (pp. 48-78). Boston, MA: Routledge \& Kegan Paul.

Foucault, M. (1995). Discipline and punish: The birth of the prison (A. Sheridan, Trans.). New York, NY: Vintage Books. (Original work published 1975)

Francis, B., \& Hey, V. (2009). Talking back to power: Snowballs in hell and the imperative of insisting on structural explanations. Gender and Education, 21(2), 225-232.

Fraser, N. (1995). From redistribution to recognition? Dilemmas of justice in a "post-socialist" age. New Left Review, 1(212), 68-93.

Fraser, N. (1997). Justice Interruptus: Critical reflections on the "postsocialist" condition. New York, NY: Routledge.

Fraser, N. (2009). Feminism, capitalism, and the cunning of history. New Left Review, 56, 97-117.

Fraser, N., \& Honneth, A. (2003). Redistribution or recognition? A political-philosophical exchange. London, UK: Verso.

Freedman, E. B. (2003). No turning back: The history of feminism and the future of women. New York, NY: Ballantine.

Grambs, J. D. (1982). Mom, apple pie, and the American dream. Social Education, 47(6), 405-409.

Hahn, C., Bernard-Powers, J., Crocco, M. S., \& Woyshner, C. (2007). Gender equity in social studies. In S. S. Klein (Ed.), Handbook for achieving gender equity through education (pp. 335-357). Mahwah, NJ: Lawrence Erlbaum.

Hahn, C., Bernard-Powers, J., Hunter, L., Groves, S., MacGregor, M., \& Scott, K. (1985). Sex equity in social studies. In S. S. Klein (Ed.), Handbook for achieving sex equity through education (pp. 280-297). Baltimore, MD: John Hopkins University Press.

Haraway, D. (1988). Situated knowledges: The science question in feminism and the privilege of partial perspective. Feminist Studies, 14(3), 575-599.

Harvey, D. (2007). A brief history of neoliberalism (2nd ed.). Oxford, UK: Oxford University Press.

Hurren, W. (2002). Gender issues within the discursive spaces of social studies education. Canadian Social Studies, 36(3). Retrieved from http://www.quasar.ualberta.ca/css/Css_36_3/ARdiscursive_ spaces.html

Langer, H. (1982). Confessions of a second-look liberal. Social Education, 46(7-8), 516-524.

Langer, H. (1983a). The women's movement: What N.O.W.? Social Education, 47(2), 112-121. 
Langer, H. (1983b). The impact of personality on history: An interview with William L. Shirer. Social Education, 47(6), 444-448.

Langer, H. (1984). Man with a hunting license: An interview with Art Buchwald. Social Education, 48(2), 103-106.

Lather, P. (1991). Getting smart: Feminist research and pedagogy within the postmodern. New York, NY: Routledge.

Lather, P. (1996). Troubling clarity: The politics of accessible language. Harvard Educational Review, 66(3), 525-545.

MacLure, M. (2003). Discourse in educational and social research. Buckingham, UK: Open University Press.

Maher, F. A. (1987). Inquiry teaching and feminist pedagogy. Social Education, 51(3), 186-188, 190-192.

Mazzei, L. A. (2004). Silent listenings: Deconstructive practices in discourse-based research. Educational Researcher, 33(2), 26-34.

Miller, J. (1996). School for women. London, UK: Virago.

Mills, S. (2004). Discourse (2nd ed.). London, UK: Routledge.

Mohanty, C. T. (1988). Under western eyes: Feminist scholarship and colonial discourses. Feminist Review, 30, 61-88. doi:10.1057/fr.1988.42

Moraga, C., \& Anzaldúa, G. (Eds.). (1981). This bridge called my back: Writings by radical women of color. Watertown, MA: Persephone Press.

Nicholson, L. (1997). Introduction. In L. Nicholson (Ed.), The second wave: A reader in feminist theory (pp. 2-5). New York, NY: Routledge.

Nickell, P., \& Kennedy, M. (1987). Global perspectives through children's games. Social Education, 51(3), 1-8.

Prior, L. (2003). Using documents in social research. Thousand Oaks, CA: Sage.

Rich, A. C. (1976). Of woman born: Motherhood as experience and institution. New York, NY: Norton.

Rich, A. C. (1986). Blood, bread, and poetry: Selected prose, 1979-1985. New York, NY: Norton.

Richardson, L., \& St. Pierre, E. A. (2005). Writing: A method of inquiry. In N. K. Denzin \& Y. S. Lincoln (Eds.), Handbook of qualitative research (3rd ed., pp. 959-978). Thousand Oaks, CA: Sage.

Ryan, B. (1992). Feminism and the women's movement: Dynamics of change in social movement ideology, and activism. New York, NY: Routledge.

Scott, J. A. (1983). A teaching tool: John Hersey's Hiroshima. Social Education, 47(7-8), 512-513.

Scott, J. W. (1988). Deconstructing equality-versus-difference. Feminist Studies, 14(1), 33-50.

Segall, A. (2004). Social studies and the discourses of postmodernity. In C. Woyshner, J. Watras \& M. S. Crocco (Eds.), Social education in the twentieth century (pp. 160-175). New York, NY: Peter Lang.

Segall, A. (2006). Critical social studies: Where do we go from here? In A. Segall, E. Heilman \& C. Cherryholmes (Eds.), Social studies - the next generation: Re-searching in the postmodern (pp. 247250). New York, NY: Peter Lang.

Segall, A. (2010). What is the connection between curriculum and instruction? In W. C. Parker (Ed.), Social Studies Today (pp. 225-234). New York, NY: Taylor \& Francis.

Smith, D. E. (1987). The everyday world as problematic: A feminist sociology. Boston, MA: Northeastern University Press.

Spivak, G. S. (1974). Translator's preface. In Jacques Derrida, Of Grammatology (G. S. Spivak, Trans.) (pp. ix-lxxxiii). Baltimore, MD: Johns Hopkins University Press.

St. Pierre, E. A. (2000). Poststructural feminism in education: An overview. International Journal of Qualitative Studies in Education, 13(5), 477-515. 
Stronach, I., \& MacLure, M. (1997). Educational research undone: The postmodern embrace. Buckingham, UK: Open University Press.

Tetreault, M. K. T. (1987). Women, gender, and the social studies. Social Education, 51(3), 167-168.

Trinh, M. (1986). Difference: A special third world women issue. Discourse, 8, (Fall-Winter), 11-37.

Totten, S. (1983). A nuclear arms race unit for classroom teachers. Social Education, 47(7-8), 507-510.

Weedon, C. (1997). Feminist practice E poststructuralist theory (2nd ed.). Oxford, UK: Blackwell Publishers.

Young, I. M. (2008). Unruly categories: A critique of Nancy Fraser's dual systems theory. In K. Olsen (Ed.), Adding insult to injury: Nancy Fraser debates her critics (pp. 89-106). London, UK: Verso.

\section{About the Author}

Mardi Schmeichel is a doctoral candidate in Social Studies Education at the University of Georgia, Athens, GA 30602. She can be contacted at: mardi@uga.edu. 